\title{
EQUILIBRIUM AND THEMODYNAMIC STUDIES OF ANIONIC DYES REMOVAL BY AN ANIONIC CLAY-LAYERED DOUBLE HYDROXIDE
}

\author{
(Kajian Keseimbangan dan Termodinamik dalam Penyingkiran Pewarna Anionik daripadaTanah \\ Liat Anionik-Dwi Hidroksida Berlapis) \\ Nesamalar Kantasamy* and Siti Mariam Sumari \\ School of Chemistry and Environment, \\ Faculty of Applied Sciences, \\ Universiti Teknologi MARA, 40450 Shah Alam, Selangor, Malaysia. \\ *Corresponding author: nesam337@salam.uitm.edu.my
}

Received: 24 February 2015; Accepted: 27 October 2015

\begin{abstract}
Adsorption isotherm describes the interaction of adsorbates with adsorbent in equilibrium. Equilibrium data was examined using Langmuir and Freundlich isotherm models. Thermodynamic studies were used to evaluate the thermodynamic parameters; heat of enthalpy change $\left(\Delta \mathrm{H}^{\circ}\right)$, Gibbs free energy change $\left(\Delta \mathrm{G}^{\circ}\right)$ and heat of entropy change $\left(\Delta \mathrm{S}^{\circ}\right)$ in order to gain information regarding the nature of adsorption (exothermic or endothermic). Four reactive dyes of anionic type, Acid Blue 29 (AB29), Reactive Black 5 (RB5), Reactive Orange 16 (RO16) and Reactive Red 120 (RR120) were used to obtain equilibrium isotherms at $25{ }^{\circ} \mathrm{C}, 35^{\circ} \mathrm{C}, 45^{\circ} \mathrm{C}$ and $55^{\circ} \mathrm{C}$. Based on Giles' classification, the isotherm produced were of L2-type, indicating strong dye affinity towards the adsorbent, and with weak competition with the solvent molecules for active adsorption sites. Equilibrium data fitted both Langmuir and Freundlich isotherm models with high correlation coefficient $\left(R^{2}>0.91\right)$ indicating the possibility of both homogeneity and heterogeneous nature of adsorption. The negative values of $\Delta \mathrm{G}^{\circ}$ indicate the adsorption processes were spontaneous and feasible. The negative values of $\Delta \mathrm{H}^{\circ}$ lie between -20 to $-75 \mathrm{~kJ} / \mathrm{mol}$, suggesting these processes were exothermic and physical in nature. The negative values of $\Delta \mathrm{S}^{\circ}$ are indication of decreased disorder and randomness of spontaneous adsorption of reactive dyes on layered double hydroxide as adsorbent.
\end{abstract}

Keywords: anionic dyes, layered double hydroxides, equilibrium isotherm, thermodynamic parameters

\section{Abstrak}

Isoterma penjerapan menerangkan interaksi antara bahan dijerap dan bahan jerap yang berada dalam keseimbangan. Data keseimbangan yang diperolehi dianalisis menggunakan model Langmuir dan Freundlich. Kajian termodinamik digunakan untuk menilai parameter-parameter termodinamik; perubahan haba entalpi $\left(\Delta \mathrm{H}^{\circ}\right)$, perubahan tenaga Gibbs bebas $\left(\Delta \mathrm{G}^{\circ}\right)$ dan perubahan haba entropi $\left(\Delta \mathrm{S}^{\circ}\right)$. Ia bertujuan untuk mendapatkan maklumat mengenai jenis penjerapan (eksoterma atau endoterma). Empat pewarna reaktif jenis anion iaitu, Asid Biru 29 (AB29), Reaktif Hitam 5 (RB5), Reaktif Jingga 16 (RO16) dan Reaktif Merah 120 (RR120) digunakan untuk mendapatkan isoterma keseimbangan pada suhu $25{ }^{\circ} \mathrm{C}, 35^{\circ} \mathrm{C}, 45^{\circ} \mathrm{C}$ dan $55^{\circ} \mathrm{C}$. Berdasarkan klasifikasi Giles, isoterma yang dihasilkan adalah jenis L2, yakni menandakan bahawa pewarna-pewarna ini mempunyai afiniti tinggi kepada bahan penjerap, dan mempunyai persaingan lemah dengan molekul-molekul pelarut untuk menambat kepada tapak atau permukaan aktif bahan penjerap. Data keseimbangan yang diperolehi didapati sesuai dipadankan dengan model isoterma Langmuir dan Freundlich dengan pekali korelasi yang tinggi (R2 > 0.91), menunjukkan kemungkinan wujud kedua-dua ciri kehomogenan dan heterogen untuk proses penjerapan. Nilai negatif $\Delta \mathrm{G}^{\circ}$ menunjukkan proses penjerapan adalah spontan dan boleh dilaksanakan. Nilai negatif $\Delta \mathrm{H}^{\circ}$ adalah antara -20 dan $-75 \mathrm{~kJ} / \mathrm{mol}$, dan ini mencadangkan proses penjerapan adalah eksoterma dan fizikal. Nilai negatif $\Delta \mathrm{S}^{\circ}$ adalah petanda penurunan gangguan dan kerawakkan penjerapan spontan pewarna reaktif pada bahan penjerap dwi hidroksida berlapis. 
Kata kunci: pewarna anion, dwi hidroksida berlapis, isoterma keseimbangan, parameter termodinamik

\section{Introduction}

Adsorption isotherm used in adsorption studies describes the interaction of adsorbates with adsorbent in equilibrium. It provides insight into adsorption mechanism, surface properties and affinity of adsorbent. Consequently it may be used to compare the properties of different adsorbents quantitatively and explicate the adsorption state of adsorbate on adsorbent surface. Equilibrium data can be analysed using isotherm models such as Langmuir and Freundlich expressions from which equilibrium constants $\left(K_{\mathrm{L}}\right.$ and $\left.K_{\mathrm{F}}\right)$ and maximum adsorption capacity $\left(Q_{\mathrm{o}}\right)$ can be obtained. The Langmuir adsorption assumes that adsorbate molecules occur on a homogenous surface with a fixed number of adsorption sites. This results in monolayer adsorption without mutual interactions between the adsorbed molecules. The Freundlich model assumes that the dye molecules are adsorbed on the heterogeneous surfaces of the adsorbate which are characterized at different energies. Thermodynamic studies are used to evaluate the thermodynamic parameters; heat of enthalpy change $\left(\Delta \mathrm{H}^{\circ}\right)$, Gibbs free energy change $\left(\Delta \mathrm{G}^{\circ}\right)$ and heat of entropy change $\left(\Delta S^{\circ}\right)$. These thermodynamic parameters reveal information regarding the nature of adsorption (exothermic or endothermic) and the spontaneity of the adsorption process [1]. If the rate of reaction increases with increase in temperature, the reaction is endothermic. Endothermic adsorption is characterised by increased adsorption capacity and which may involve chemisorption. If an increase in temperature results in decreased adsorption capacity, adsorption is exothermic, which most likely involves physisorption. The objective of this study is to examine and evaluate the adsorption properties of an anionic clay-layered double hydroxide for four anionic dyes (AB29, RB5, RO16 and RR120) in terms of adsorption isotherms and thermodynamic parameters.

\section{Chemicals and raw materials}

\section{Materials and Methods}

Magnesium nitrate hydrate $\left(\mathrm{Mg}\left(\mathrm{NO}_{3}\right)_{2} \cdot 6 \mathrm{H}_{2} \mathrm{O}\right)$ and Aluminum nitrate hydrate $\left(\mathrm{Al}\left(\mathrm{NO}_{3}\right)_{2} .9 \mathrm{H}_{2} \mathrm{O}\right)(\mathrm{MERCK})$ were used to synthesise the adsorbent, layered double hydroxide, $\mathrm{Mg}-\mathrm{Al}-\mathrm{NO}_{3}-\mathrm{LDH}$ by co-precipitation procedure followed by hydrothermal treatment as outlined by previous studies [2-4].The adsorbates, anionic dyes, RB5, AB29, RO16 and RR120 (Sigma Aldrich, Germany) were used to obtain four sets of equilibrium isotherms. The structures of the dyes are shown in Fig.1.

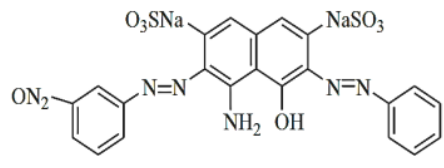

Acid blue 29 (AB29); $\mathrm{C}_{22} \mathrm{H}_{14} \mathrm{~N}_{6} \mathrm{Na}_{2} \mathrm{O}_{9} \mathrm{~S}$

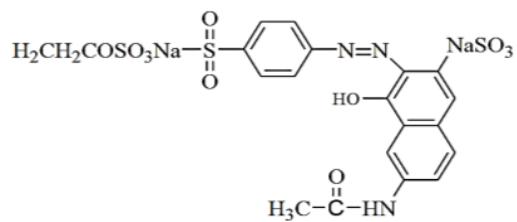

Reactive Orange 16 (RO16); $\mathrm{C}_{20} \mathrm{H}_{17} \mathrm{~N}_{3} \mathrm{Na}_{2} \mathrm{O}_{11} \mathrm{~S}$

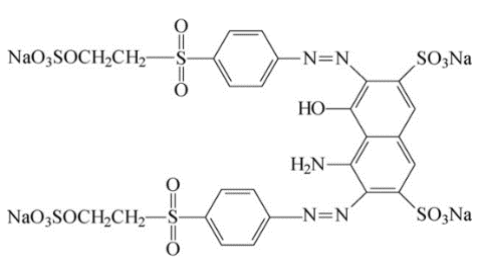

Reactive Black 5 (RB5); $\mathrm{C}_{26} \mathrm{H}_{21} \mathrm{~N}_{5} \mathrm{Na}_{4} \mathrm{O}_{19} \mathrm{~S}_{6}$

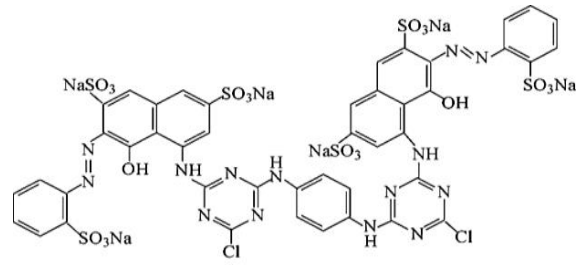

Reactive Red 120 (RR120); $\mathrm{C}_{44} \mathrm{H}_{24} \mathrm{Cl}_{2} \mathrm{~N}_{14} \mathrm{Na}_{6} \mathrm{O}_{20} \mathrm{~S}$

Figure 1. Chemical structure of anionic dyes 


\section{Adsorption Equilibrium}

Adsorption equilibrium between adsorbent anionic clay layered double hydroxide $\left(\mathrm{MgAlNO}_{3}\right.$ - $\left.\mathrm{LDH}\right)$ and adsorbates in single dye solution was attained in 24 hours in a water bath shaker operating at $100 \mathrm{rpm}$ and maintained at different temperatures $\left(25^{\circ} \mathrm{C}, 35^{\circ} \mathrm{C}, 45^{\circ} \mathrm{C}\right.$ and $55^{\circ} \mathrm{C}$ or $298 \mathrm{~K}, 308 \mathrm{~K}, 318 \mathrm{~K}$ and $\left.328 \mathrm{~K}\right)$. For comparison purposes the initial $\mathrm{pH}$ of all dye solutions were kept constant at $\mathrm{pH} 5.5 \pm 0.5$ (using dilute $\mathrm{HCl}$ and $\mathrm{NaOH}$ ) which lies in the range of optimum $\mathrm{pH}$ of dyes solutions. A concentration range of $10-100 \mathrm{mg} / \mathrm{L}$ of single dye solutions was allowed to contact with the adsorbent $(0.02 \mathrm{~g} / 50 \mathrm{~mL})$. Based on the equilibrium data of isotherms, the thermodynamic parameters were calculated.

\section{Effect of solution temperature on percentage dye removal}

\section{Results and Discussion}

The effect of temperature on percentage dye removal for AB29, RB5, RO16 and RR120 are given in Fig. 2 (a)-(d). It was found that the uptake of the dyes by the adsorbent decreased with increasing temperature from $25{ }^{\circ} \mathrm{C}$ to 55 ${ }^{\circ} \mathrm{C}$, indicating energy was released as a result of adsorption. General surface adsorption by anionic dye onto layered double hydroxides can be represented by the expression in equation 1 :

LDH-surface + Dye

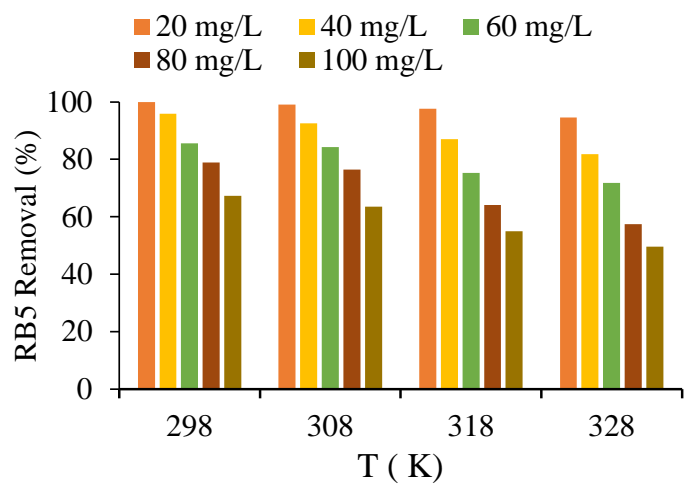

(a) RB5

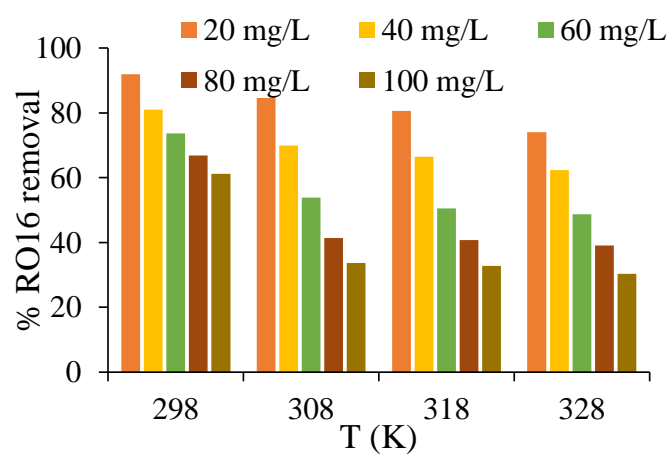

(c) $\mathrm{RO} 16$
LDH-Surface $/$ Dye

(b) AB29

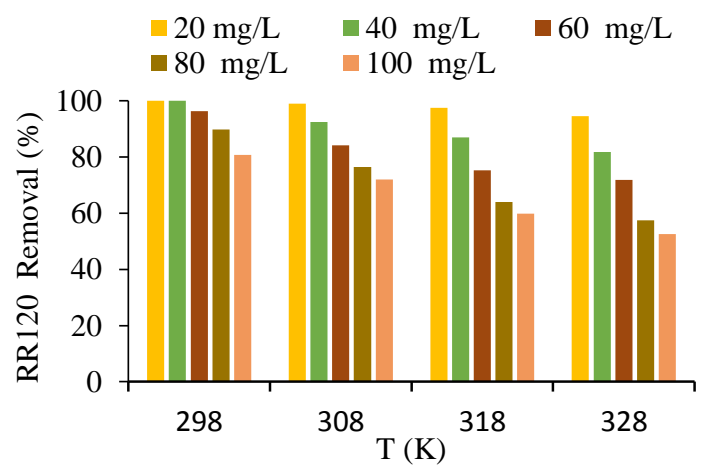

(d) RR120

Figure 2. Effect of temperature on percentage removal of anionic dyes by LDH (a) RB5 (b) AB29, (c) RO16 (d) RR120 at different temperatures 
This type of adsorption is deemed exothermic in nature [5-7]. This scenario is equivalent to increase in energy content of the system, with a reduction of surface activity [8] and the probability of colliding molecules capturing one another, thus requiring the adsorbent to have more energy [7]. Therefore the resulting reduction in the rate of adsorption may also be explained by the tendency of dye molecules to escape from the solid phase to bulk phase as temperature was increased [9].

The exothermic nature of anionic dye adsorption conforms to most adsorption of dyes including reactive dyes using various adsorbents. Examples from previous studies of exothermic adsorption are the uptake of Remazol Black B by Rhizopus arrhizus [8] and RO16 onto AC (Ananas comosus (L.)) [10].

\section{Adsorption Isotherm}

The relationship between the amount of adsorbate adsorbed on the adsorbent's surface and in liquid state when equilibrium state is achieved at constant temperature is often represented by curves $\left(q_{\mathrm{e}}\right.$ vs $\left.C_{\mathrm{e}}\right)$ called adsorption isotherm. Adsorption isotherm is characterized by constants which are functions of surface properties, affinity and adsorption capacity of adsorbents [8]. Fig. 3(a)-(d) shows the adsorption isotherms for RB5, AB29, RO16 and RR120. The shapes of the isotherm give the first diagnostic tool to obtain information about the nature of adsorption. This information is vital for an engineer in order to optimize the design parameters for adsorption system, besides aiding him to establish the most appropriate correlation for equilibrium curves. Auta \& Hameed [11] and Giles \& Smith [12] classified these isotherms into four main categories: L, S, H and C. Based on the Giles' classification, the isotherms produced correspond to the L-type (sub-group 2 or H). L-type isotherms display concavity toward the abscissa axis and are characteristics of high affinity of adsorbed molecules towards adsorbents. In L-type isotherms, a monolayer formation (plateau) is established. Fig. 3 (a)-(d) indicates that the reactive dyes were effectively removed at lower concentration while higher initial concentrations tend to reach maximum capacity as indicated by the plateau. As such the anionic dyes used in this study can be considered as favourably removed from solutions with low competition from water molecules onto substrates (LDH) until at high solute (dye) concentration when the surface coverage reached maximum [13].

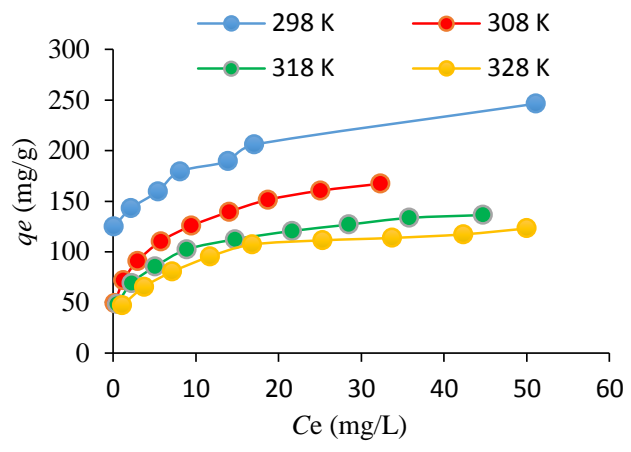

(a) RB5

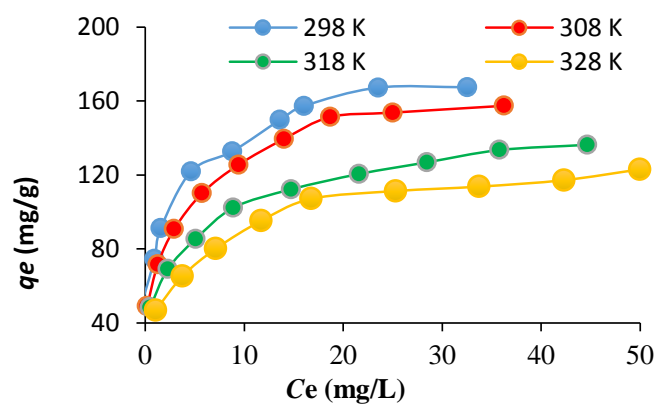

(c) RO16

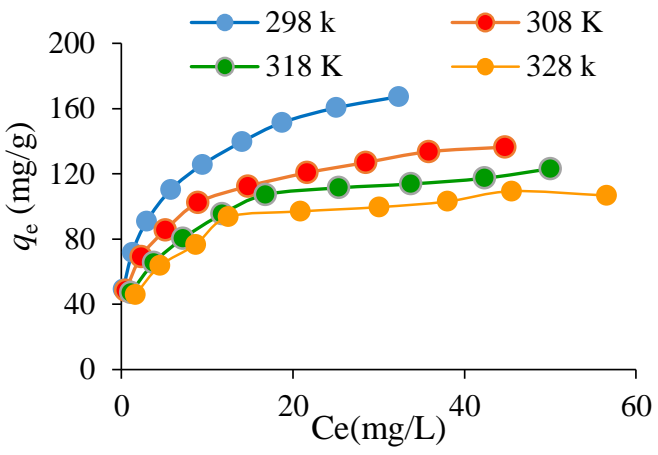

(b) AB29

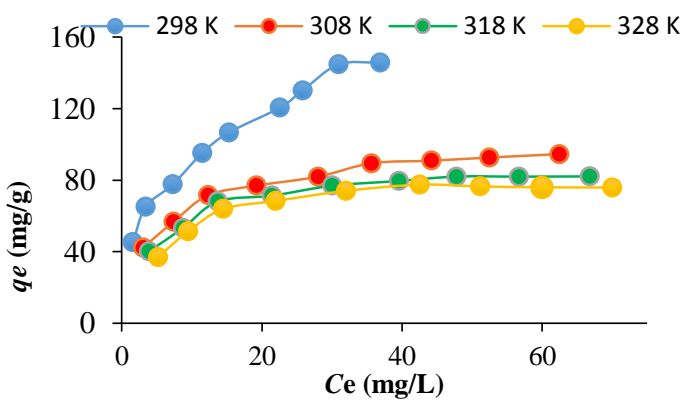

(d) RR120

Figure 3. Adsorption isotherms for dyes- LDH (a)-(d): RB5, AB29, RO16, RR120 at different temperatures 


\section{Adsorption isotherms modeling}

Quantification of dye removal and the use of equilibrium models offer insight into the characterization of these solid surfaces especially on heterogeneity of the adsorbent surface. Two well-known and widely used models, the Freundlich and Langmuir isotherms, have been adopted to explicate dye-clay interaction. To account for the relevance of these two isotherm models, the values of Langmuir and Freundlich parameters correlation coefficients, $R^{2}$ at various temperatures together with their respective constants were obtained from the linear plots. The linearised Langmuir equation (1) can be presented graphically in the form of $\left(C_{\mathrm{e}} / q_{\mathrm{e}}\right)$ vs $C_{e}$ in Fig.4 (a)-(d).

$$
\frac{\mathrm{C}_{\mathrm{e}}}{\mathrm{q}_{\mathrm{e}}}=\frac{1}{\mathrm{Q}_{\mathrm{o}} \mathrm{K}_{\mathrm{L}}}+\frac{\mathrm{C}_{\mathrm{e}}}{\mathrm{Q}_{\mathrm{o}}}
$$

$C_{\mathrm{e}}=$ dye concentration at equilibrium, $\mathrm{mg} / \mathrm{L} ; q_{\mathrm{e}}=$ adsorption capacity at equilibrium, $\mathrm{mg} / \mathrm{g}$ and $\mathrm{Q}_{\mathrm{o}}=$ maximum monolayer capacity $(\mathrm{mg} / \mathrm{g}) ; K_{L}=$ Langmuir constant related to the free energy of adsorption;

The linearized Freundlich equation is given in equation 2

$$
\log \mathrm{q}_{\mathrm{e}}=\log \mathrm{K}_{\mathrm{F}}+\frac{1}{\mathrm{n}} \log \mathrm{C}_{\mathrm{e}}
$$

The Freundlich constant, $n$, reflects both the average binding energy and the energetic heterogeneity of the sorbent binding sites [14]. The constant, $\mathrm{K}_{\mathrm{F}}$ indicates adsorption capacity. As shown in Fig. 5, the plot of $\ln \mathrm{q}_{\mathrm{e}}$ versus $\ln \mathrm{C}_{\mathrm{e}}$ is employed to determine the value of $\mathrm{K}_{\mathrm{F}}$ and $\mathrm{n}$ from intercept and slope respectively.

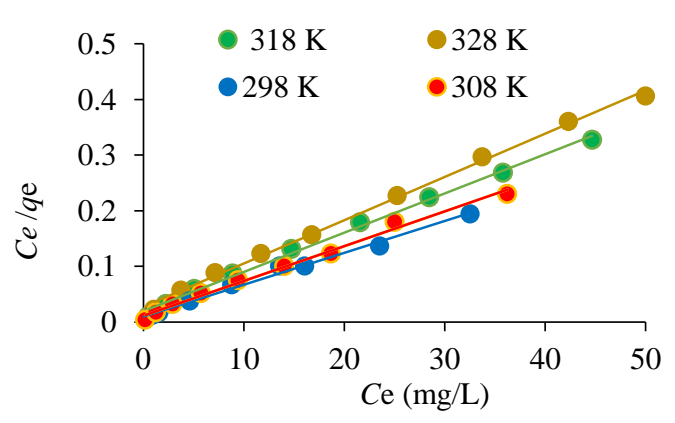

RB5

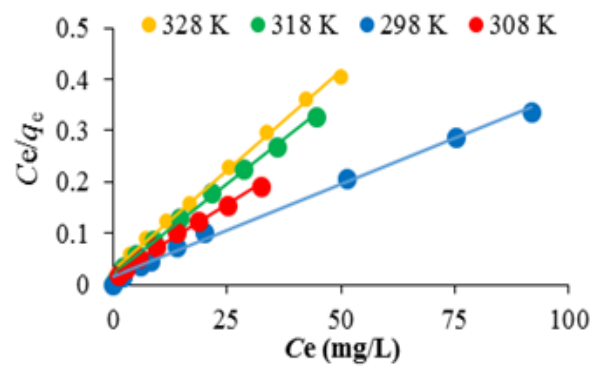

(c) $\mathrm{RO} 16$

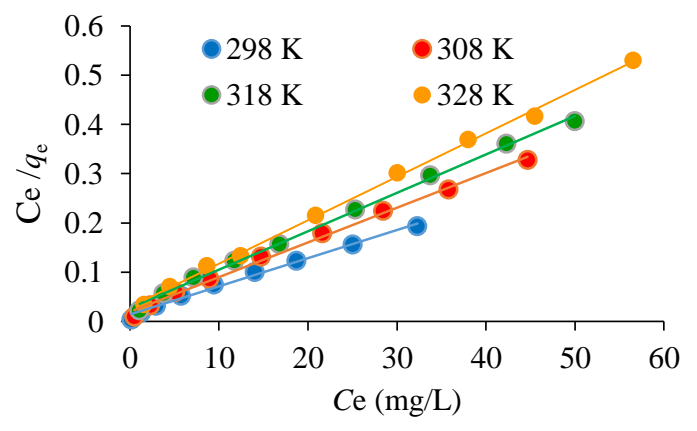

AB29

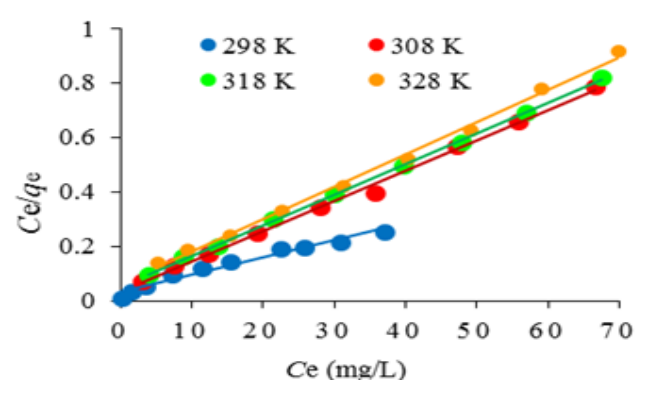

(d) RR120

Figure 4. Langmuir isotherm at different temperatures for (a) AB29 (b) RB5 (c) RO16 (d) RR120 


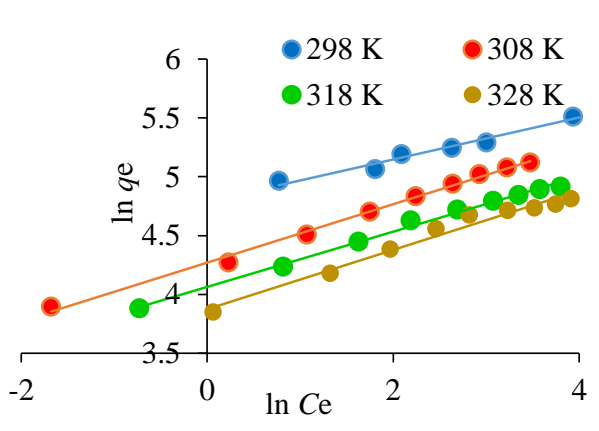

(a) RB5

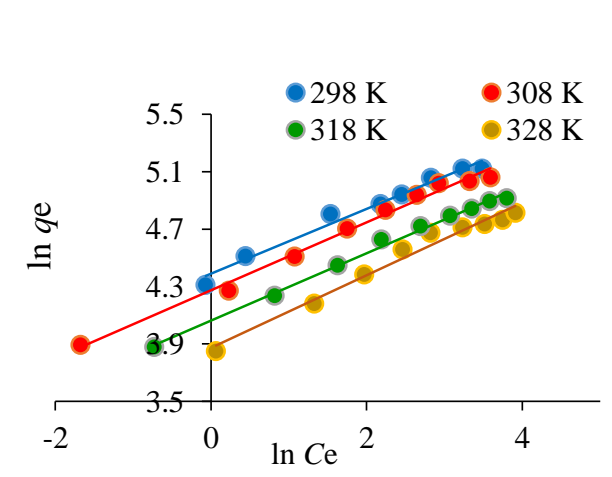

(c) RO16

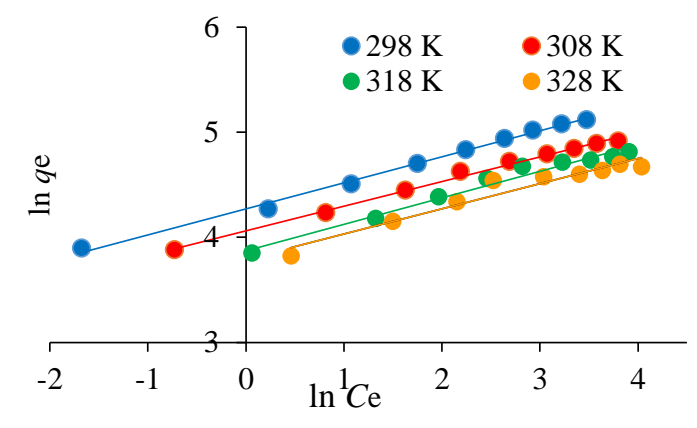

(b) AB29

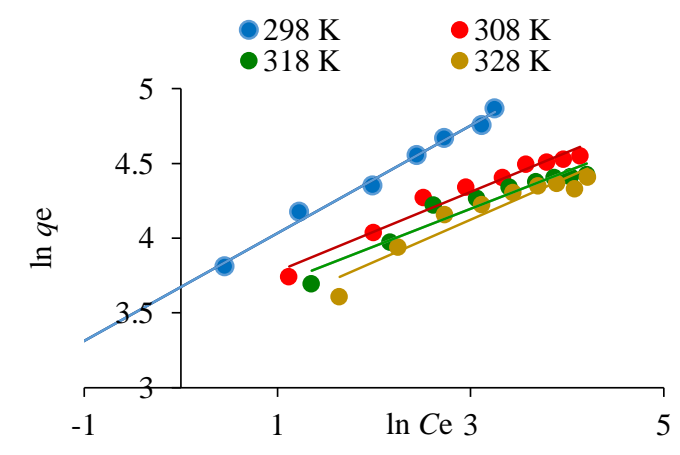

(d) RR120

Figure 5. Freundlich isotherm at different temperatures for (a) AB29 (b) RB5 (c) RO16 (d) RR120

The high correlation coefficient values $\left(R^{2}=0.906-1.000\right)$ for Langmuir and Freundlich $(0.91-1.00)$ models strongly imply the fact that the dye-LDH adsorption closely follows both Langmuir and Freundlich models of adsorption under the present experimental conditions. This finding is not unusual as previous study by Ip et al [15] also found that adsorption of RB5 by bamboo activated carbon followed a hybrid of Langmuir and Freundlich equations. The dye binding capacities reflected by maximum monolayer adsorption capacities, $Q_{\mathrm{o}}(\mathrm{mg} / \mathrm{g})$ were found to be in the order: RB5 (277.8) > AB29 (186.4) > RO16 (172.4) > RR120 (166.7).

\section{Thermodynamics of adsorption}

Analysis of thermodynamic parameters reveals negative values of $\Delta \mathrm{G}^{\circ}$, indicating that the process of adsorption was spontaneous and feasible. The values of negative $\Delta \mathrm{G}^{\circ}$ also decreased slightly as temperature was increased from $298 \mathrm{~K}$ to $328 \mathrm{~K}$, showing that the adsorption process was thermodynamically feasible at room temperature but less with higher temperatures. The negative values of enthalpy change, $\Delta \mathrm{H}^{\circ}$ confirm the exothermic nature of dyeLDH adsorption system. In this study, the negative values of $\Delta \mathrm{H}^{\circ}$ lie between -20 to $-75 \mathrm{~kJ} / \mathrm{mol}$ suggesting the process was physical in nature. The negative values of $\Delta \mathrm{S}^{\circ}$ are indication of decreased disorder and randomness of spontaneous adsorption of reactive dyes on the adsorbent.

\section{Conclusion}

The high correlation coefficient values $\left(R^{2}=0.906\right.$ - 1.000) of anionic dyes indicate the adsorption equilibrium data was well described by Freundlich and Langmuir isotherm models suggesting the existence of more than a single mechanism in adsorption of anionic dyes by LDH. In this case the conformity to Langmuir implied homogeneity and second order reaction, meanwhile the compliance to Freundlich indicate the heterogeneity. The adsorption 
capacity of RB5, AB29, RO16 and RR120 onto LDH decreased with increasing temperature indicating exothermic adsorption. The affinity of anionic dyes towards LDH followed the order: RB5 > AB29 > RO16 > RR120. Thermodynamically, dye uptake was spontaneous and exothermic and mainly physical in nature.

\section{References}

1. Auta, M. and Hameed, B. H. (2012). Modified mesoporous clay adsorbents for adsorption isotherm and kinetics of methylene blue. Chemical Engineering Journal, 198: 219 - 227.

2. Reichle, W. T. (1986). Synthesis of anionic clay minerals (mixed metal hydroxides, hydrotalcite). Solid State Ionic, 22: $135-141$.

3. Forano, C., Hibino, T., Leroux, F. and Taviot-Gue' Ho, G. (2006). Layered double hydroxides. Developments in Clay Science, 1: 1021 - 1095.

4. Kameda, T., Yamazaki, T. \& Yoshioka, T. (2009). Preparation of MgAl layered double hydroxide intercalated with 2,7-Naphthalene Disulfonate and its selective uptake of aromatic compounds from aqueous solutions. Bulletin of the Chemical Society of Japan, 82: 1436 - 1440.

5. Al-Ghouti, M., Khraisheh, M. A. M., Ahmad, M. N. M. and Allen, S. (2005). Thermodynamic behavior and the effect of temperature on the removal of dyes from aqueous solution using modified diatomite. Journal of Colloid and Interface Science. 287: 6 - 13.

6. Meroufel, B., Benali, O., Benyahia, M., Benmoussa, Y., and Zenasni, M. A. (2013). Adsorptive removal of anionic dye from aqueous solutions by Algerian kaolin: Characteristics, isotherm, kinetic and thermodynamic studies. Journal of Material Environmental Science, 4: 482 - 491.

7. Kobiraj, R., Gupta, N., Kushwaha, A. K. and Chattophadhyaya, M. C. (2012). Determination of equilibrium, kinetic and thermodynamic parameters for the adsorption of the brilliant green dye from aqueous solutions onto eggshell powder. Indian Journal of Chemical Technology, 20: 26 - 31 .

8. Aksu, Z., \& Tezer, S. (2000). Equilibrium and kinetic modelling of biosorption of Remazol Black by Rhizopus arrhizus in a batch system: effect of temperature .Process Biochemistry, 36:431 - 439.

9. Venkatesha, T. G., Viswanatha, R., Arthoba, Y. N. and Chethana, B. K. (2012). Kinetics and thermodynamics of reactive and vat dyes adsorption on MgO nanoparticles. Chemical Engineering Journal, 198-199: 1-10.

10. Ramachandran, P., Vairamuthu, R. and Sivakumar, P. (2011). Adsorption isotherms, kinetics, thermodynamics and desorption studies of Reactive orange 16 on activated carbon derived from Ananas comosus (L.) Carbon, ARPN. Journal of Engineering and Applied Sciences. 6 (11): 15 - 26.

11. Auta, M. \& Hameed, B.H. (2011). Optimized waste tea activated carbon for adsorption of Methylene Blue and Acid Blue 29 dyes using response surface methodology. Chemical Engineering Journal, 175: 233 - 243.

12. Giles, C. H. \& Smith, D. (1974). General treatment and classification of the solute sorption isotherms. Journal of Colloid and Interface Science, 47: 755 - 765.

13. Al-Degs, Y. S., El-Barghouthi, M. I., El-Sheikh, A. H. and Walker, G.M. (2008). Effect of solution pH, ionic strength, and temperature on adsorption behavior of reactive dyes on activated carbon. Dyes Pigments, 77: $16-$ 23.

14. Vega, F. A. I., Covelo, E. F. and Andrade, M.L. (2011). Applying Freundlich, Langmuir and Temkim Models in $\mathrm{Cu}$ and $\mathrm{Pb}$ Soil Sorption Experiments. Spanish Journal of Soil Science, 1(1): 20 - 37.

15. Ip, A. W. M., Bradford, J. P., and McKay, G. (2010). A comparative study on the kinetics and mechanisms of removal of Reactive Black 5 by adsorption onto activated carbons and bone char. Chemical Engineering Journal, 57: $434-442$. 